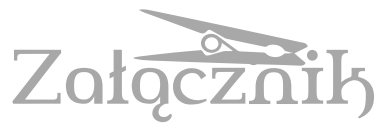

DOI 10.21697/zk.2021.8.07

\title{
NOTATKI FILMOWE PIERA PAOLA PASOLINIEGO NA TLE LITERACKIEJ I FILMOWEJ POETYKI BRULIONU ${ }^{1}$
}

ROBERT BIRKHOLC

Instytut Literatury Polskiej UW

Faculty of Polish Studies, University of Warsaw rbirkholc@uw.edu.pl

ORCID 0000-0002-5192-4997

\section{NOTATKI FILMOWE A INNE NIEFIKCJONALNE FORMY AUTOTEMATYCZNE}

Od ponad dekady można zaobserwować wzrastające zainteresowanie filmoznawców esejem audiowizualnym, rozumianym jako hybrydyczny gatunek charakteryzujący się antysystemowością, niekonkluzywnością i tendencją do łączenia różnych dyskursów². Usytuowany pomiędzy kinem dokumentalnym, kinem fikcjonalnym i awangardą, esej traktowany jest często jako forma praktycznego uprawiania filozofii kina, co czyni go wyjątkowo atrakcyjnym przedmiotem badawczym dla teoretyków. Autorefleksyjny potencjał eseju w pełni ujawnia się w tzw. notatkach, niefikcjonalnych fil-

1 Artykuł powstał w ramach grantu MINIATURA 3 przyznanego przez Narodowe Centrum Nauki (numer rejestracyjny wniosku: 2019/03/X/HS2/01991).

2 Zob. m.in.: T. Corrigan, The Essay Film. From Montaigne, After Marker, New York 2001; D. Montero, Thinking Images. The Essay Film as a Dialogic Form in European Cinema, Bern 2012; L. Rascaroli, The Personal Cinema. Subjective Cinema and the Essay Film, New York 2009; B. Zając, Między słowem a obrazem. Dyskurs eseju filmowego, „Kwartalnik Filmowy” 2010, nr 71-72, s. 75-96; L. Rascaroli, How the Essay Film Thinks, Oxford-New York 2017; Essays on the Essay Film, eds. N.M. Alter, T. Corrigan, New York 2017; a także teksty zebrane w: „Kwartalnik Filmowy” 2018, nr 104. Na temat różnic w definiowaniu eseju zob. G. Świętochowska, Wideoesej, czyli od Chrisa Markera do Fandoru. Historia awansu pewnej formy audiowizualnej wyrosłej z kinofilii, „Kwartalnik Filmowy” 2018, nr 104, s. 7. 
mach poświęconych przygotowaniom do realizacji innych dzieł filmowych. Utwory te, reżyserowane przede wszystkim przez Piera Paola Pasoliniego, ale też Federica Felliniego i Andrieja Tarkowskiego, miały przedstawiać proces artystyczny i być swego rodzaju komentarzem filmowców do swojej twórczości. Notatki przez długi czas nie były przedmiotem pogłębionej refleksji i dopiero w ostatnich latach stają się obiektem zainteresowania filmoznawców ${ }^{3}$, przy czym badania dotyczą głównie Notatek do Orestei afrykańskiej (1973) Pasoliniego i, z uwagi na tematykę dzieł włoskiego reżysera, ogniskują się na wątkach postkolonialnych. Nowatorstwo tych utworów zostało już co prawda dostrzeżone, jednak warto rozszerzyć spostrzeżenia badaczy i skoncentrować się na brulionowej formie filmów, które, jak zauważa Laura Rascaroli, tworzą odmianę, a może nawet podgatunek eseju audiowizualnego ${ }^{4}$. Przedmiotem analizy będą filmy Piera Paola Pasoliniego, ponieważ włoski reżyser posługiwał się formą notatek trzykrotnie i stworzył najbardziej złożone dzieła z tej grupy. Dodatkowym kontekstem warto uczynić analogiczne formy literackie - notatki poświęcone pisaniu opowiadań i powieści zamieszczane przez autorów w dziennikach czy sylwach - ponieważ filmowo-literackie zestawienie pomoże w rozpoznaniu swoistych cech notatek audiowizualnych.

Zarówno notatki literackie, jak i notatki filmowe są przejawem szerszych zjawisk dokonujących się w kulturze w drugiej połowie XX wieku, takich jak nasilenie się autorefleksyjności i wzrastająca rola para- oraz metatekstów. Analizując niefikcjonalne „filmy o filmie”, trzeba jednak przede wszystkim zwrócić uwagę na semiotyczną odmienność dzieł filmowych od literackich, a także na zupełnie inny sposób ich kreacji. Porównanie użyte przez producenta Giana Vittoria Baldiego, twierdzącego, że Pasolini tworzył Notatki do Orestei afrykańskiej tak, jakby pisał wiersz bądź esej ${ }^{5}$, to wyłącznie efektowna

3 Także w Polsce - zob.: P. Kletowski, Między dokumentalnym ujęciem a kreacją. Dokufilmy Pier Paolo Pasoliniego, „Kultura Popularna” 2013, nr 1(35), s. 40-47; T. Szerszeń, Szyby Afryki, „Widok. Teorie i Praktyki Kultury Wizualnej” 2014, nr 7 [czasopismo internetowe], http://widok.hmfactory.com/index.php/one/article/view/221/385, [dostęp 13.03.2020].

4 Zob. L. Rascaroli, op. cit.

5 Zob. wywiad z Baldim zamieszczony na DVD: Interviste video a Gian Vittorio Baldi, [w:] P.P. Pasolini, Appunti per un'Orestiade Africana, Cineteca di Bologna 2009. 
figura retoryczna, wymagająca krytycznej weryfikacji. Sytuacja reżysera, który wraz z ekipą filmową podróżuje po świecie w poszukiwaniu lokacji i aktorów do przyszłego dzieła fikcjonalnego, jest diametralnie inna od sytuacji literata samotnie piszącego dziennik pomysłów twórczych ${ }^{6}$. Dostępna technologia, stopień wolności twórczej, artystyczny wkład członków ekipy czy sposób dystrybucji filmów to czynniki, które poniekąd warunkują formę notatek filmowych, dlatego charakterystykę tej odmiany eseju audiowizualnego należy rozpocząć od przedstawienia szerzej nieznanych ${ }^{7}$ faktów dotyczących produkcji filmów. Warto zbadać również, na ile forma ta była przez Pasoliniego wykorzystywana świadomie i jak kształtowała się jej koncepcja. Informacje zewnątrztekstowe uzupełnią i wzbogacą opis poetyki notatek filmowych włoskiego reżysera. Choć w analizowanych dziełach można dostrzec cechy charakterystyczne dla literackiej formy brulionu - takie jak subiektywizm, dialogiczność, wariantywność - to jednak najistotniejsze wydaje się to, w jaki sposób medium audiowizualne przekształca i modeluje dyskurs autotematyczny ${ }^{8}$.

Obok notatek można wyróżnić również inne rodzaje eseistycznych oraz dokumentalnych „filmów o filmie”, w których reżyserzy dokonują swego rodzaju auto(re)prezentacji swojej pracy twórczej. Filmy niefikcjonalne mogą być autoreferencyjne i tematyzować proces własnego powstawania bądź też opowiadać o innych dziełach filmowych. Utwory należące do drugiej grupy można sklasyfikować według kryterium relacji temporalnej między

6 Określenia „dziennik pomysłów twórczych” używa m.in. Erazm Kuźma. Zob. E. Kuźma, Między konstrukcją a destrukcją, Szczecin 1994, s. 142.

7 Informacje na temat produkcji notatek filmowych Pasoliniego zebrałem, studiując materiały dostępne w Centro Studi - Archivio Pier Paolo Pasolini w Cineteca di Bologna. Bardzo dziękuję kierownikowi archiwum Roberto Chiesiemu za pomoc i konsultację.

8 Pojęcia ,autotematyzm”, wprowadzonego do dyskursu naukowego przez Artura Sandauera, używam zgodnie z definicją Wojciecha Browarnego, rozszerzając ją jednak także na teksty filmowe. Jak pisze badacz, „autotematyzm w sensie węższym to nazwa typu literatury, w którym dominującą rolę grają refleksje dotyczące celów i sposobów pisania, konwencji artystycznych i metod budowania dzieła". Zob. W. Browarny, Opowieści niedyskretne: formy autorefleksyjne w prozie polskiej lat dziewięćdziesiątych, Wrocław 2002, s. 29. 
filmem X (autotematycznym filmem niefikcjonalnym) a filmem Y (filmem, o którym opowiada film X). Relacja ta może opierać się na:

a. uprzedniości X względem Y;

b. równoległości X i Y;

c. uprzedniości Y względem $\mathrm{X}^{9}$.

W pierwszej sytuacji niefikcjonalne filmy opowiadają o dziełach jeszcze nienakręconych i skupiają się na etapie preprodukcji - przedstawiają proces pisania scenariusza, poszukiwanie lokacji bądź castingi aktorskie. Do grupy tej zaliczają się zarówno filmy dokumentalne utrzymane w klasycznej formie, takie jak W poszukiwaniu Tadzia (1970) Luchina Viscontiego, jak i notatki będące odmianą eseju audiowizualnego: Wizja lokalna w Palestynie (1964), Notatki do filmu o Indiach (1970) i Notatki do Orestei afrykańskiej Pasoliniego, Notatnik reżysera (1969) Felliniego, Czas podróży (1980) Tarkowskiego i Notatki na temat filmu „Zdrowaś Mario” (1983) Jean-Luca Godarda.

Relacja równoległości zachodzi wówczas, kiedy film X zawiera materiały nakręcone na planie filmu Y i przedstawia proces jego produkcji. Choć zazwyczaj obrazy tego typu, nazywane making-ofami, zostają ukończone już po realizacji dzieł, o których opowiadają, to jednak często przedstawiają one pracę nad filmami jako work-in-progress. Trzeci typ można określić mianem autorskich glos - są to utwory, w których reżyserzy powracają do dzieł już zrealizowanych i komentują je z perspektywy czasu. Za prekursorskie pod tym względem można uznać utrzymane w konwencji „gadających głów” Filmując Otella (1978) Orsona Wellesa, w którym legendarny reżyser nie tylko opowiadał o produkcji swojego filmu z 1952 roku, ale też przedstawiał jego interpretację. Wydaje się, że po pojawieniu się nośnika DVD funkcję autorskich glos spełniają dostępne na płytach audiokomentarze twórców, których można słuchać, symultanicznie oglądając film. Zaproponowany podział ma jedynie modelowy charakter, zaś w praktyce pojawiają się często

9 Inny podział proponuje Tomasz Kożuchowski, który dzieli niefikcjonalne „filmy o filmie" na: a) rekonstrukcje przedstawiające chronologicznie proces produkcji filmu; b) refleksje przedstawiające wspomnienia osób, które uczestniczyły w realizacji filmu; c) substytuty opowiadające o filmach, które nie powstały. Notatki filmowe można by zaliczyć do tej ostatniej kategorii, choć autor nie wspomina o utworach Pasoliniego. Zob. T. Kożuchowski, Making-of. (Nie)zwykły dodatek, „Ekrany” 2019, nr 3-4, s. 70-74. 
formy łączone i niekiedy trudno określić, co jest przykładowo making-ofem, a co glosą $a^{10}$. Można ponadto wyróżnić odrębny gatunek autoportretu artystycznego, w którym reżyser nie opowiada o konkretnym dziele, ale o całej swojej twórczości bądź o metodzie swojej pracy, jak to się dzieje np. w Portrecie Wernera Herzoga (1986).

Punktem wspólnym wszystkich wymienionych filmów jest ich metatekstualny charakter, jednak zasadniczo różnią się one zarówno pod względem zastosowanych konwencji, jak i ambicji artystycznych. Jeśli chodzi o potencjał autorefleksyjny, notatki szczególnie wyróżniają się na tym tle, ponieważ źródłem namysłu nad możliwościami filmowego wyrazu są w nich nie tylko wypowiedzi twórców, ale też eseistyczna forma przekazu. Poza tym metatekstualność jest tu niejako wirtualna, tym bardziej, że dzieła, o których filmy opowiadają, czasem w ogóle nie były później realizowane. Notatki stawiają pytania o możliwość stworzenia fabularnych utworów fikcjonalnych, a wybrana przez reżyserów otwarta, brulionowa forma staje się rodzajem artystycznego manifestu.

Notatki filmowe trudno byłoby uznać za reprezentację konkretnego gatunku literackiego, ponieważ w literaturze nie ukonstytuował się osobny gatunek niefikcjonalnych utworów w całości poświęconych przygotowaniom do napisania dzieł literackich. Określenie „notatki” stanowi w przypadku przekazów pisanych istotną wskazówkę paratekstualną, ale nie jest wyznacznikiem gatunkowym i bywa stosowane zarówno w odniesieniu do form fikcjonalnych, jak i niefikcjonalnych. Podstawowe cechy konotowane przez to pojęcie to: brak wykończenia, charakter wstępny i przygotowawczy, (często symulowana) spontaniczność zapisu i swoboda twórcza ${ }^{11}$. Skupiając

10 Zdarzają się przypadki szczególnie złożone, jak Pogoda domu niechaj będzie $z$ toba (1979) Andrzeja Wajdy. Dokumentalny film przedstawia wizytę Jarosława Iwaszkiewicza w dworku w Byszewach, gdzie początkowo miały być kręcone Panny $z$ Wilka (1979). Film ten opowiada więc o fazie preprodukcji (poszukiwanie lokacji), ale konfrontuje materiał dokumentalny ze scenami nakręconego później dzieła fikcjonalnego - co ciekawe, w dużej mierze z tymi fragmentami, które ostatecznie nie zostały włączone do Panien $z$ Wilka.

${ }_{11}$ Przykładowo Jerzy Andrzejewski pisze o tworzeniu Notatek do autobiografii: "Jeżeli tylko notatki, to raczej tylko rodzaj przygotowania do autobiografii, swobodny wybór zebranych materiałów, możliwość luzów w zakresie własnego JA, a także 
się na płaszczyźnie autorefleksyjnej, warto uczynić punktem odniesienia dla filmów Pasoliniego wyłącznie notatki literackie na temat pisania opowiadań bądź powieści, zawierające refleksje nad planowanymi dziełami oraz próbne, „robocze” wersje przyszłych utworów. Nie tworzą one co prawda odrębnego gatunku, ale są włączane w obręb większych form i stanowią często istotną część dzienników literackich oraz sylw. Zdarza się - choć nie jest to regułą że takie autotematyczne fragmenty są wyraźnie wyodrębnione i opatrzone tytułem (np. Jerzy Andrzejewski umieszcza w swoich dziennikach uwagi dotyczące planowanego opowiadania, nazywając je Notatkami do „Teraz na ciebie zagłada"12). Oparty na relacji temporalnej podział niefikcjonalnych „filmów o filmie" nie daje się przy tym w pełni zastosować w odniesieniu do literatury, ponieważ proces pisania nie rządzi się tak sformalizowanymi procedurami, jak tworzenie filmów i w większości wypadków trudno byłoby orzec, czy autotematyczne komentarze są „uprzednie” czy też „równoległe” wobec powstających powieści bądź opowiadan ${ }^{13}$. Warto ponadto zaznaczyć, że autorefleksyjne utwory o pisaniu często naruszają granicę między prozą fikcjonalną a niefikcjonalną ${ }^{14}$.

Jako forma realizująca poetykę brulionu, do której cech należą m.in. fragmentaryczność, hybrydyczność, improwizacja, niewykończenie, metatekstualność ${ }^{15}$, autotematyczne notatki literackie są przejawem nasilającej się od lat sześćdziesiatych XX wieku tendencji do odrzucania fikcjonalnych, zamkniętych struktur na rzecz konwencji autobiograficznych i refleksji

w stosunku do własnego JA" [wyróżnienia oryginalne]. Zob. J. Andrzejewski, $Z$ dnia na dzień 1976-1979, tom 2, Warszawa 1988, s. 299.

12 Ibidem, s. 245.

13 Istotniejszy wydaje się więc tu podział na powieści dopiero powstające i już napisane. Przykładem glosy autorskiej mógłby być np. Jak powstał doktor Faustus Tomasza Manna. Zob. T. Mann, Jak powstał doktor Faustus. Powieść o powieści, tłum. M. Kurecka, Warszawa 1962.

${ }^{14}$ Klasycznymi polskimi przykładami są Góry nad Czarnym Morzem Wilhelma Macha, w których narrator przedstawia autotematyczne refleksje na temat pisania powieści oraz Miazga Jerzego Andrzejewskiego. Zob. W. Mach, Góry nad Czarnym Morzem, Warszawa 1961; J. Andrzejewski, Miazga, Wrocław 2002.

15 Zob. T. Burek, Zamiast powieści, Warszawa 1971, s. 35; R. Nycz, Sylwy wspótczesne, Kraków 1996, s. 14-16. 
warsztatowych ${ }^{16}$. Tomasz Burek zwraca uwagę na to, że brulion, improwizacja, szkic lepiej niż tradycyjna powieść pozwalają oddać dynamiczną rzeczywistość, która nie chce się zmaterializować w „rzeczy nieśmiertelnej w arcydziele"17. Autotematyczne fragmenty poświęcone pisaniu mają nie tylko przybliżyć okoliczności powstawania utworu, lecz przede wszystkim ukazać sam proces tworzenia, „to mroczne pogranicze między pomysłem a dziełem skończonym, zamkniętym"18. Stają się one środkiem do obnażenia konwencji literackich, destrukcji fabuły, podważenia wszechwiedzy narratora, a także formą pozwalającą na sproblematyzowanie kategorii autora oraz sytuacji nadawczo-odbiorczej. Bardzo często notatki literackie są nie tyle marginalnym metatekstem dzieł fabularnych, ile intencjonalnym świadectwem niemożności ich stworzenia.

Jeśli chodzi o notatki audiowizualne, to pojęcie to nie pojawia się w podręcznikach filmoznawczych, lecz zostało przeszczepione na grunt filmu przez samych twórców. Podczas gdy pierwszy esej audiowizualny o przygotowaniach do realizacji dzieła fikcjonalnego został nazwany przez Pasoliniego bardziej technicznym terminem „wizji lokalnej”, to już dwa kolejne noszą miano „notatek do filmu” (wł. appunti per un film). Pojęcia „notatek” (fr. notes) używał również Jean-Luc Godard, a Federico Fellini posłużył się pokrewnym określeniem „notatnika” (ang. block-notes). Obrazy te (wraz z Czasem podróży Tarkowskiego) łączy nie tylko zakres tematyczny, ale też gatunkowa forma eseju oraz podejmowana przez twórców refleksja nad medium przedstawienia i specyfiką znaków filmowych. Wydaje się, że idee przyświecające reżyserom notatek filmowych są w dużej mierze zbieżne z intencjami pisarzy posługujących się formą brulionu - filmowcy przesuwają punkt ciężkości z wytworu na proces wytwarzania, pokazują swoją pracę „od kuchni” i dzielą się rozmaitymi wątpliwościami twórczymi.

16 Zob. B. Bakuła, Oblicza autotematyzmu, Poznań 1991, s. 52.

17 T. Burek, op. cit., s. 35.

18 E. Kuźma, op. cit., s. 147-148. 


\section{KSZTAŁTOWANIE SIĘ FORMUŁY NOTATEK W FILMACH PASOLINIEGO}

Co interesujące, sama formuła notatek nie powstała jednak wcale w wyniku estetycznych przemyśleń twórców. Za pierwszy utwór tego typu można uznać Wizję lokalna w Palestynie, która przedstawia relację z podróży Piera Paola Pasoliniego do Izraela i Jordanii w poszukiwaniu lokacji oraz aktorów do Ewangelii według Mateusza (1964). Pomysłodawcą projektu nie był jednak sam Pasolini, ale producent Alfredo Bini, który chciał zaprezentować inwestorom i dystrybutorom pracę wstępną wykonaną nad Ewangelią ${ }^{19}$. Materiał przygotowawczy, nagrany w Palestynie przez operatorów Otella Martelliego i Alda Pinelliego przy jedynie niewielkich uwagach reżysera ${ }^{20}$, miał pełnić funkcję pomocniczą i dopiero później powstał pomysł stworzenia z niego filmu. Pasolini nie brał nawet udziału w pracach montażowych, lecz - poproszony przez producenta - dodał jedynie swój komentarz spoza kadru i prawdopodobnie zadecydował o podkładzie muzycznym. Paradoksalnie więc „autor” notatek nie był odpowiedzialny za użycie najbardziej podstawowych środków „języka” filmowego. Pomimo to, dzięki komentarzowi Pasoliniego, Wizja lokalna w Palestynie może jawić się jako utwór osobisty i na wskroś autorski. Komentarz reżysera nie jest bowiem wyłącznie dodatkiem do obrazu, ale elementem powodującym rekonfigurację znaczeń, które w przekazie filmowym powstają na skutek interakcji słowa i obrazu.

Wizja lokalna $w$ Palestynie oraz późniejsze notatki Pasoliniego wykorzystują elementy dziennika podróży i dokumentu etnograficznego, co wynika z faktu, że reżyser poszukiwał lokacji oraz aktorów do swoich mitycznych dzieł poza europejskim kręgiem kulturowym. Obraz z 1964 roku przedstawia „pielgrzymkę" twórcy do miejsc pojawiających się w Nowym Testamencie, takich jak Nazaret, Jerozolima i Betlejem, przy czym wędrówka po Palestynie to dla Pasoliniego także podróż wewnętrzna, w czasie której

19 Sponsorem podróży było stowarzyszenie Pro Civititate Christiana, dlatego Wizja lokalna $w$ Palestynie była później pokazywana w kościołach.

20 Pasolini prosił jedynie czasem operatorów, aby sfilmowali określone pejzaże. Reżyser nie wiedział jeszcze wtedy, że z materiałów tych ma powstać film niefikcjonalny. Zob. P.P. Pasolini, Pier Paolo Pasolini: A Future Life (A Cinema of Poetry), eds. L. Betti. Lazio 1989, s. 59. Zob. też: Pasolini on Pasolini, Interviews With Oswald Stack, London 1969, s. 73. 
krystalizuje się idea filmu o Chrystusie. Za motto Wizji może posłużyć fragment Pisma Świętego, cytowany na końcu utworu przez reżysera: „Bóg wybrał [...] to, co nie jest szlachetnie urodzone według świata i wzgardzone, i to, co nie jest, wyróżnił Bóg, by to co jest, unicestwić" (1 Kor 1: 27-29) Miejsca biblijne, takie jak Jezioro Tyberiadzkie czy rzeka Jordan, pomyślane wcześniej jako tło do przyszłego filmu, wydały się twórcy małe i zadziwiające w swej prostocie. Pasolini doszedł jednak do wniosku, że nie ma sensu kręcić Ewangelii w Palestynie - zindustrializowane, nowoczesne miasta izraelskie zbytnio przypominają bowiem współczesną Europę, a przestrzenią znacznie bardziej „zsakralizowaną” wydały się twórcy skromne obszary wiejskie, które z łatwością można było odnaleźć także we włoskiej Puglii czy Kalabrii. Pasolini zaznacza, że jakkolwiek wizja lokalna odniosła praktyczne fiasko, była dla niego bardzo istotna, ponieważ potwierdziła jego wcześniejsze intuicje estetyczne. Ewangelia według Mateusza została ostatecznie zrealizowana we Włoszech, przy czym reżyser odtwarzając biblijną krainę w ubogich włoskich rejonach, inspirował się tym, co zobaczył w Izraelu i Jordanii.

Wizja lokalna $w$ Palestynie podporządkowana jest linearnej strukturze podróży, w której kolejne etapy wyznaczane są wizytami w miejscach związanych z postacią Chrystusa. Twórcy nie ograniczają się jednak do przedstawiania biblijnych miast, ale pokazują też ludzi i miejsca zobaczone „po drodze". Przykładowo reżyser zbacza z głównej trasy, by spotkać się z Druzami - religijno-etniczną grupą łączącą wpływy chrześcijańskie i muzułmańskie - bądź z plemieniem Beduinów. Pojawiające się w tych scenach duże zbliżenia autochtonów, przywołujące na myśl stylistykę fabularnych dzieł reżysera, w pełni wpisują się w antropologiczny projekt twórcy, który szukał w Izraelu i Jordanii (a później także w krajach afrykańskich oraz w Indiach) twarzy „,niewinnych”, nienaznaczonych jeszcze zachodnim konsumpcjonizmem. Pasolini odnajduje tę niewinność w Druzach i Beduinach, jednak nie dostrzega $w$ ich fizjonomiach i sposobie bycia śladów mentalności chrześcijańskiej, dlatego uznaje, że nie mogliby zagrać w Ewangelii. Izraelscy mieszczanie wydają się z kolei reżyserowi zbyt nowocześni, przez co również nie wpisują się w jego wizję starożytnej Palestyny. Przeprowadzona w Izraelu i Jordanii „wizja lokalna” skłania Pasoliniego do przekonania, że nie może

${ }^{21}$ Cyt. za: Biblia Tysiąclecia. Pismo Święte Starego i Nowego Testamentu, wydanie V, 2002. 
zrealizować swojej koncepcji dzieła o Chrystusie z udziałem autochtonicznej społeczności - nie tylko z przyczyn czysto produkcyjnych, ale też antropologicznych.

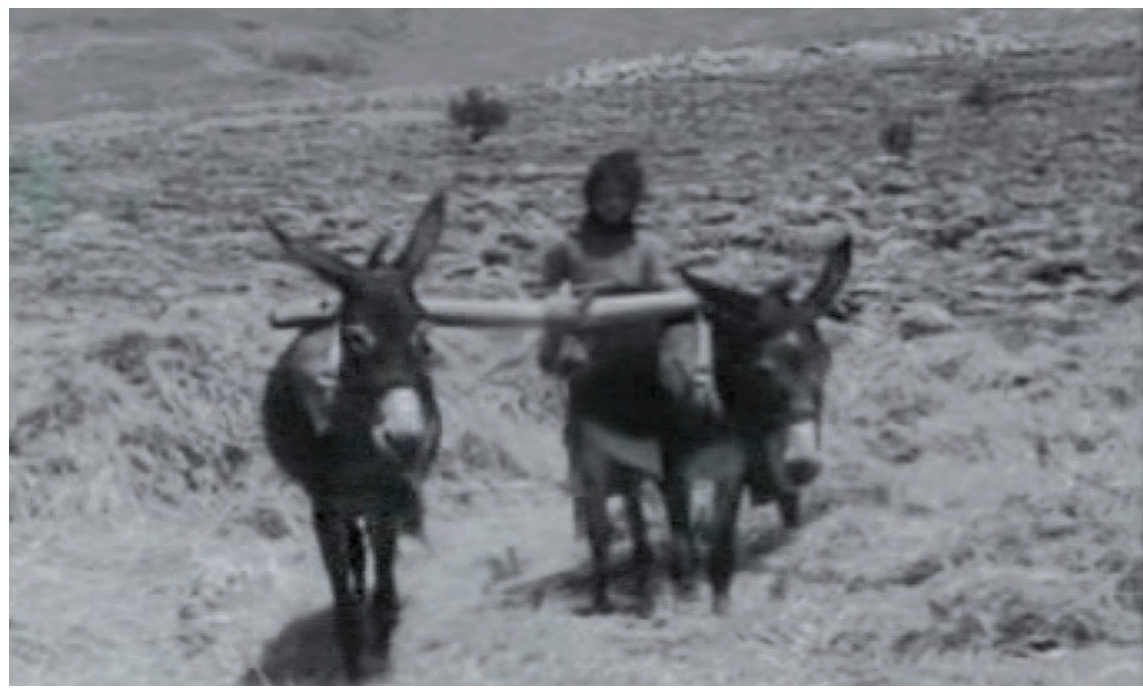

Il. 1. „Osty z Biblii, mała dziewczynka z Biblii...”. Kadr z filmu Wizja lokalna w Palestynie

Podczas gdy sceny z Druzami i Beduinami mogą być potraktowane jako swego rodzaju wstęp do castingu do Ewangelii, w Wizji lokalnej zdarzają się też wątki dygresyjne niezwiązane z planowaną adaptacją, np. utrzymany $\mathrm{w}$ konwencji cinéma-vérité fragment, w którym reżyser z mikrofonem w ręku zadaje pytania członkom izraelskiego kibucu. Chropowata technicznie, niedbale zmontowana ${ }^{22}$ i charakteryzująca się niską jakością dźwięku Wizja lokalna w Palestynie nosi znamiona reportażu, jednak konwencja ta zostaje przełamana. Obok scen opierających się na prostej rejestracji rzeczywistości przed kamerą pojawiają się ujęcia mające silnie estetyczny wymiar. Najlepszym tego przykładem jest fragment z druzyjską dziewczynką wykonującą samotnie pracę w polu, który zaczyna się od długiej panoramy

22 Sam Pasolini nazwał niektóre cięcia „paskudnymi”, jednak postanowił nie zmieniać nic w montażu. Zob. Pasolini on Pasolini..., s. 73. 
pokazującej dziecko na tle górskiego krajobrazu. Brak jakichkolwiek artefaktów nowoczesności sprawia, że scena ta równie dobrze mogłaby rozgrywać się w czasach biblijnych. Komentarz pozakadrowy Pasoliniego nadbudowuje nad obrazem nowe znaczenia, umieszczając go w kontekście planowanej adaptacji (,krajobraz sprzed 2000, 3000, 5000 lat, osły z Biblii, mała dziewczynka z Biblii" ${ }^{23}$; zob. il. 1). Scena zostaje ponadto uwznioślona przez podkład muzyczny - arię Buss und Reu z Pasji według świętego Mateusza Johanna Sebastiana Bacha ${ }^{24}$. Choć komentarz Pasoliniego nie pozwala zapomnieć o dokumentalnym charakterze ujęć, to jednak fragment ten można potraktować jako hipotetyczne ujęcie z adaptacji Ewangelii. Wydaje się, że palestyńska Ewangelia Pasoliniego może zaistnieć tylko w formie takich przebłysków, fragmentarycznych ujęć, notatek właśnie - ostatecznie reżyser odrzucił pomysł kręcenia filmu fabularnego w Izraelu i Jordanii, ponieważ odnalazł na miejscu zbyt mało podobnych obrazów.

Można przypuszczać, że to właśnie okoliczności powstania Wizji lokalnej - która została zmontowana z materiałów niemających początkowo składać się na oddzielny film i nie była skierowana do szerokiej publiczności - zadecydowały poniekąd o tym, że w utworze znalazły się wątki poboczne i dygresyjne. Formuła stworzona w tym eseju, wynikająca w dużej mierze z czynników niezależnych od reżysera, została rozwinięta przez Pasoliniego - już zupełnie świadomie - w Notatkach do filmu o Indiach. $\mathrm{W}$ drugiej połowie lat sześćdziesiątych reżyser miał zamiar zrealizować $\mathrm{w}$ Indiach film zainspirowany hinduskimi legendami, opowiadający o maharadży, który, przepełniony litością, oddaje się na pożarcie głodującemu tygrysowi. Hinduska tradycja uosabiana przez maharadżę miała być skonfrontowana z rzeczywistością współczesnych Indii, przedstawioną w drugiej

${ }^{23}$ Cytaty z filmu w tłumaczeniu własnym.

${ }^{24}$ Ścieżka dźwiękowa w Wizji lokalnej w Palestynie nie jest redundantna i modyfikuje znaczenia obrazu. Fragmenty Pasji według świętego Mateusza towarzyszą filmowi od samego początku, przy czym pełnią różne funkcje. Wydaje się, że czasem mają uwznioślać obraz, np. po wypowiedzi Pasoliniego poruszonego niewielkimi rozmiarami Jordanu, pojawia się ujęcie rzeki, któremu towarzyszy podniosły fragment $D a$ das Jesus merkete z utworu Bacha, co można interpretować w kontekście estetycznego odkrycia reżysera o wielkości rzeczy małych. W innych momentach muzyka pozostaje jednak jeśli nie w kontrapunkcie, to z pewnością w napięciu z obrazem. 
części opowieści, ukazującej tułaczkę wdowy i osieroconych dzieci po pogrążonym w biedzie kraju. W krótkim szkicu Historia indyjska Pasolini zaznacza, że będzie mógł dopracować konstrukcję dzieła dopiero po wykonaniu dokumentacji w Indiach ${ }^{25}$, a relację z owej wyprawy przygotowawczej przedstawiają właśnie Notatki do filmu o Indiach, które w odróżnieniu od Wizji lokalnej od początku były pomyślane jako odrębny utwór. Realizacja projektu o bardzo niskim potencjale komercyjnym byłaby trudna, gdyby nie sprzyjające czynniki instytucjonalne - w 1963 roku kanał RAI zaczął emitować niezwykle zasłużone w historii włoskiej telewizji pasmo informacyjne TV7, w ramach którego podejmowano niewygodne i kontrowersyjne tematy $^{26}$. Realizując film dla TV7, Pasolini, który udał się do Indii jedynie z kilkoma współpracownikami ${ }^{27}$, miał dużą swobodę twórczą.

Reportaż napisany podczas produkcji Notatek do filmu o Indiach jest świadectwem tego, że przystępując do realizacji tego utworu, reżyser nie miał jeszcze pewności, czy będzie w przyszłości robił film fabularny. W wywiadzie udzielonym Romano Coście Pasolini podkreśla, że jeśli „wizja lokalna” nie potwierdzi jego hipotezy roboczej na temat sytuacji w Indiach, zrezygnuje $\mathrm{z}$ realizowania dzieła pełnometrażowego ${ }^{28}$. Notatki do filmu o Indiach są więc nie tyle obrazem o problemach związanych z preprodukcją, co utworem konfrontującym koncepcję reżysera z rzeczywistością „prefilmową” i stawiającym pytania (natury intelektualnej i artystycznej, a nie pragmatycznej) o samą możliwość zrealizowania utworu fikcjonalnego o Indiach. Reżyser jest świadomy, że zaproponowana przezeń formuła notatek odbiega od

25 Zob. szkic Indian Story, [w:] P.P. Pasolini, A Future Life..., s. 93-95. Szkic został opublikowany w 1967 roku. Warto dodać, że Pasolini jeździł do Indii od początku lat sześćdziesiątych.

26 Zob. M. De Palma, Pasolini. Il Documentario di poesia, Aleksandria 2009, s. 120. Notatki do filmu o Indiach zostały wyemitowane w TV7 5 lipca 1970 roku, a w późniejszym okresie pokazywane były na festiwalach filmowych.

${ }^{27}$ Reżyser pojechał do Indii z operatorami Federiciem Zannim i Robertem Nappą, reżyserem dźwięku Giannim Barcellonim, przyjacielem Ninettem Davolim i dziennikarzem Romano Costą; zob. R. Costa, L’India di Pasolini, „Vie Nuove”, 25.01.1968; [przedruk w:] P.P. Pasolini, Le Regole Di Un'Illusione. I film, il cinema, a cura di L. Betti, M. Gulinucci, Rzym 1991, s. 173.

28 Ibidem, s. 174. 
konwencjonalnego kina dokumentalnego, o czym świadczą wypowiedziane na początku dzieła słowa: „Nie jestem tu, by zrobić dokument ani reportaż, robię film o filmie na temat Indii”.

Notatki do filmu o Indiach zaczynają się od syntetycznej serii obrazów, przedstawiających m.in.: Bramę Indii, sępy pochłaniające padlinę, żebrzącego Hindusa, siedzibę indyjskiego parlamentu i flagę Republiki Indii, tak jakby twórca już na wstępie chciał wskazać na wielość płaszczyzn (kulturowych, politycznych, egzystencjalnych), jakie należałoby uwzględnić, realizując film na temat tego kraju. W dalszej części utworu reżyser pokazuje miejsca oraz ludzi, którzy mogliby ewentualnie wystąpić w jego fabularnym dziele o Indiach, ale przede wszystkim próbuje zweryfikować swoją wstępną hipotezę, starając się dowiedzieć od przedstawicieli różnych grup społecznych, czy ofiarna postawa maharadży jest zrozumiała dla współczesnych Hindusów. Ta część, utrzymana w stylu cinéma-vérité, jest uzupełniona rozmowami z robotnikami, chłopami, intelektualistami i politykami na temat zagadnień dotyczących aktualnej sytuacji Indii, takich jak: modernizacja, przymusowa sterylizacja czy stosunek do kasty niedotykalnych. Pasolini bada, czy współczesne Indie zachowały swoją tradycję kulturową w obliczu nasilającej się westernizacji i czy w związku z tym parabola stworzona przez niego na użytek filmu fabularnego znajduje uzasadnienie.

Pomimo że niektóre sceny są utrzymane w reportażowym stylu, Notatki do filmu o Indiach realizują formułę eseju filmowego w większym stopniu niż Wizja lokalna w Palestynie. Struktura filmu ma znacznie luźniejszy charakter, ponieważ nie jest już podporządkowana chronologii podróży, ale dyskursowi Pasoliniego, który za pomocą słowa i montażu nieustannie narusza czasoprzestrzenne continuum. Kiedy na początku Notatek reżyser przedstawia koncepcję filmu fabularnego, kamera pokazuje indyjskie obrazy i freski z motywami mitycznymi, a montaż zestawia niektóre $\mathrm{z}$ nich $\mathrm{z}$ ujęciami współczesnych Indii. Zabieg ten może być kluczem do rozpoznania kompozycji całego filmu, który opiera się na konfrontowaniu mitu z rzeczywistością, fikcyjnej opowieści z realiami ${ }^{29}$. Perspektywa mityczna

29 Filmoznawcy wielokrotnie podkreślali, że jednym z kluczowych elementów poetyki kina Pasoliniego jest figura analogii polegająca na łączeniu odległych czasowo i przestrzennie płaszczyzn, znajdująca doskonałe odzwierciedlenie w jego adaptacjach mitów, takich jak Król Edyp (1967) i Medea (1969). Zob. m.in.: A. Maggi, The 
jest w Notatkach do filmu o Indiach nakładana na obraz za pośrednictwem słowa, a także poprzez montaż i muzykę - tym razem muzycznym lejtmotywem jest wykonywana na flecie melancholijna kantata sakralna Gottes Zeit ist die allerbeste Zeit Bacha. Utwór ten stanowi podkład muzyczny m.in. w symbolicznym finale filmu przedstawiającym ceremonię spalenia zwłok ${ }^{30}$, w którym Indie jawią się jako „kraina sakralna” ${ }^{31}$, zamieszkana przez uduchowionych ludzi zdolnych do poświęcenia i z pokorą znoszących swój los. Ubodzy Hindusi wydają się co prawda przystawać do wyobrażeń reżysera związanych z przyszłym filmem fabularnym, ale zawodzi koncepcja postaci maharadży, ponieważ indagowani przez twórcę przedstawiciele wyższych warstw społecznych są zwesternizowani i nie potrafią w pełni zrozumieć ofiarniczej postawy władcy z mitycznej opowieści. Choć Pasolini próbuje patrzeć na Indie przez pryzmat swojego pomysłu na film fabularny, to jednak wypowiedzi rozmówców oraz same obrazy indyjskiej rzeczywistości stawiają niekiedy opór werbalizowanym przez niego ideom ${ }^{32}$. Co znamienne, fabuła o Indiach nie została później przez reżysera zrealizowana.

Choć formuła kina niefikcjonalnego pozwala weryfikować twórcy wstępne założenia na temat Indii, Pasolini jest świadomy tego, że konwencja

Resurrection of the Body, Chicago 2009, s. 21; P. Kletowski, W kręgu mitów założycielskich - (przed) historyczne kino Piera Paola Pasoliniego, [w:] Przeszłość we współczesnej narracji kulturowej. Tom 2. Studia i szkice kulturoznawcze, red. P. Plichta, Kraków 2011, s. 171-180.

30 Co ciekawe, zakończenie to stanowi niemal ilustrację fragmentów eseju literackiego Zapach Indii, który Pasolini napisał kilka lat wcześniej. Zob. P.P. Pasolini, The Scent of India, transl. D.C. Price, London 2012, s. 77.

31 Zob. P. Kletowski, Pier Paolo Pasolini. Twórczość filmowa, Warszawa 2013, s. 213.

32 W Notatkach do filmu o Indiach istnieje niekiedy napięcie między komentarzem słownym a obrazem. Luca Caminati wskazuje np. na fragment, w którym Pasolini mówi, że w planowanym filmie fabularnym po śmierci maharadży nastąpi przejście $\mathrm{z}$ tradycyjnego indyjskiego świata do nowoczesności. Kiedy reżyser wypowiada te słowa, kamera wykonuje dynamiczną jazdę wzdłuż rurociągu, w ten sposób, że kontury obiektu niemal się zacierają. Zdaniem Caminatiego Pasolini zestawił komentarz z rozmazanym, zbliżonym do malarstwa abstrakcyjnego obrazem, by zwrócić uwage na nieprzejrzystość rzeczywistości i podkreślić, że wygłaszane przez niego tezy nie są obiektywnym opisem. Zob. L. Caminati, Orientalismo eretico. Pier Paolo Pasolini e il Cinema del Terzo Mondo, Mediolan 2007, ss. 64, 65-66. 
dokumentalna nie zapewnia bezpośredniego dostępu do rzeczywistości. Używając silnie kreacyjnych zabiegów filmowych, takich jak montaż skojarzeniowy i komentarz spoza kadru, oraz nakładając na rzeczywistość fikcjonalną historię o maharadży, Pasolini kręci film zupełnie odmienny od pozorujących obiektywizm dokumentów spod znaku direct cinema. Włoski twórca podkreśla, że jego spojrzenie na Indie jest subiektywne i akcentuje własne uwikłanie kulturowe, dlatego zastosowaną w Notatkach do filmu o Indiach strategię można uznać za praktykę postkolonialną, problematyzującą zagadnienie przedstawiania Innego ${ }^{33}$. Forma sytuujących się między kinem dokumentalnym a kinem fikcjonalnym notatek filmowych umożliwia refleksję epistemologiczną nad (nie)możliwością reprezentacji, dlatego znamienny wydaje się fakt, że Pasolini zamierzał posłużyć się tą odmianą eseju audiowizualnego także w kolejnych pięciu utworach poświęconych kulturom „niedoreprezentowanym” w zachodnim dyskursie. Projekt Notatki do poematu o Trzecim Świecie miał składać się z filmów opowiadających o: Indiach, Afryce, krajach arabskich, Ameryce Południowej i gettach w Stanach Zjednoczonych. Tym razem reżyser chciał jednak pójść o krok dalej i uznał formę notatek za jedyny właściwy sposób opowiadania o problemach Trzeciego Świata. Jak pisze Pasolini w szkicu do projektu, „ogromna ilość ideologicznego, praktycznego i politycznego materiału koniecznego do użycia $\mathrm{w}$ takim filmie wzbrania nas przed kręceniem formalnego filmu. Będzie on musiał podążać za formułą »filmu o filmie, który powinien zostać zrobiony «"34.

33 Postkolonialną interpretację Notatek przedstawia chociażby Caminati. Zdaniem badacza w pierwszej scenie filmu Pasolini celowo odwołuje się do obrazów będących źródłem stereotypowej wiedzy zachodniego człowieka o Indiach, by zaakcentować własne uwikłanie w dominujący dyskurs. Ibidem, s. 61.

${ }^{34}$ Zob. szkic reżysera Notes for a Poem on the Third World, [w:] P.P. Pasolini, My Cinema, eds. G. Chiarcossi, R. Chiesi, Bolonia 2012, s. 201. W wywiadzie z Oswaldem Stackiem Pasolini mówił z kolei, że każda z części będzie „w połowie dokumentem, a w połowie rekonesansem dotyczącym lokacji do przyszłego filmu; to będzie opowiedziane niebezpośrednio, jako historia do opowiedzenia”. Zob. Pasolini on Pasolini, Interviews..., s. 140. 
Ambitny projekt nie powiódł się, jednak Pasolini zdołał zrealizować Notatki do Orestei afrykańskiej. Wyreżyserowany dla telewizji RAI ${ }^{35}$ film jest oparty na podobnym pomyśle, co utwór o Indiach - Pasolini odwiedza kraje afrykańskie (Ugandę, Tanzanię i Ghanę), aby zweryfikować, czy mógłby nakręcić tam uwspółcześnioną wersję Orestei Ajschylosa ${ }^{36}$. Choć reżyser mówi na początku Notatek do Orestei o planowanym dziele fabularnym, to jednak wiele wskazuje na to, że w momencie przystępowania do realizacji eseju porzucił już ten pomysł i chciał pozostać wyłącznie przy „notatkowej” formie ${ }^{37}$. Sama idea osadzenia greckiej tragedii we współczesnej Afryce wynika $\mathrm{z}$ dostrzeżonej przez twórcę analogii pomiędzy procesami kulturowymi opisanymi przez Ajschylosa a społeczno-politycznymi transformacjami na tym kontynencie. Moment, w którym opanowany przez Furie Orestes ucieka z Argos po zabiciu matki i dostaje się pod opiekę Ateny, ustanawiającej pierwszy $w$ historii sąd złożony z ludzi, symbolizuje w perspektywie Pasoliniego narodziny demokratycznego świata i staje się analogonem sytuacji Afrykańczyków, zyskujących w połowie XX wieku niepodległość i wkraczających na drogę demokracji. Znakiem przejścia od cywilizacji archaicznej do nowoczesnej jest dla reżysera transformacja krwiożerczych Furii w opiekuńcze bóstwa Eumenidy, która miałaby stanowić kulminacyjny moment w hipotetycznej adaptacji.

W Notatkach do Orestei reżyser intensyfikuje tendencje obecne we wcześniejszych notatkowych utworach i tworzy film znacznie bardziej heterogeniczny pod względem stylistycznym. Na esej składają się zdjęcia dokumentalne zarejestrowane w Afryce przez Pasoliniego, materiały

${ }^{35}$ Tym razem Pasolini nie miał jednak szczęścia, jeżeli chodzi o dystrybucję. Telewizja RAI odmówiła ostatecznie zakupu filmu, co mogło być spowodowane czynnikami politycznymi. Notatki do Orestei afrykańskiej były w pierwotnej (podobno aż 95-minutowej) wersji pokazywane w 1970 roku na festiwalu w Cannes, jednak doczekały się jedynie kilku publicznych pokazów za życia reżysera. Zob. R. Chiesi, Pasolini e la 'Nuova Forma' di appunti per un'Orestiade Africana, [w:] Appunti Per Un'Orestiade Africana, a cura di R. Chiesi, Bolonia 2008, [dodatek do DVD].

36 Pasolini przedstawił projekt filmu w krótkim szkicu literackim The White Athena. Zob. P.P. Pasolini, My Cinema, op. cit., s. 143-145.

37 Twierdzi tak np. producent Notatek do Orestei afrykanskiej Gian Viittorio Baldi. Zob. Interviste video a Gian Vittorio Baldi, op. cit. 
typu found footage, sceny na wpół zainscenizowane, hipotetyczne fragmenty przyszłego filmu, a także sceny przedstawiające dyskusję reżysera z afrykańskimi studentami Uniwersytetu w Rzymie. Reżyser nieustannie przechodzi od pomysłu do pomysłu, wypróbowuje różne idee, szuka najbardziej odpowiednich środków wyrazu. W pewnym momencie seria ujęć archiwalnych zostaje np. przerwana ponad dziesięciominutową sceną występu jazzowego nagraną w studiu w Rzymie, ponieważ Pasolini wpada na pomysł, że tekst Orestei może być w jego adaptacji wyśpiewywany. Jeśli chodzi o muzykę, Notatki do Orestei także są heterogeniczne - różne style muzyczne wskazują tu na odmienne możliwości estetycznego ukształtowania adaptacji, a jednocześnie są nośnikiem znaczeń politycznych. Pasolini chce, aby adaptacja tekstu Ajschylosa stała się rewolucyjną opowieścią o wyzwoleniu Afrykańczyków, jednak wypróbowuje różne klucze stylistyczne służące wyrażeniu tej idei. Pierwszy, reprezentowany przez wykonywaną po rosyjsku pieśn socjalistyczną Warszawianka $1905^{38}$, skłania do osadzenia „afrykańskiej Orestei” w kontekście rewolucji bolszewickiej; drugi, reprezentowany przez jazz, przypomina o znaczeniu czarnoskórych ze Stanów Zjednoczonych w procesach wolnościowych zachodzących w Afryce. Podczas gdy pieśn socjalistyczna kieruje adaptację w stronę kina jawnie politycznego, muzyka jazzowa wnosi do filmu wieloznaczność, a ponadto jest zdecydowanie mocniej osadzona w afrykańskim kontekście. Kompozycje Gato Barbieriego ${ }^{39}$ monumentalizują hipotetycznych odtwórców głównych ról w Orestei, ale czasem służą także silniejszemu kreowaniu znaczeń - np. afrykańskie drzewa dopiero wespół z niepokojącą i chaotyczną muzyką mogą, zgodnie z zamysłem reżysera, reprezentować mityczne Furie.

Spojrzenie Pasoliniego na Afrykę może wydawać się tendencyjne, jednak reżyser nie próbuje obiektywizować własnej perspektywy. Co znamienne, tłem czołówki w Notatkach do Orestei są dwa leżące obok siebie

38 Warszawianka 1905 to polska pieśń socjalistyczna napisana przez Wacława Święcickiego w 1879 roku, która zyskała wielką w popularność w ZSRR w latach trzydziestych XX wieku.

39 Zapraszając do współpracy Barbieriego, Pasolini chciał uzyskać muzyczny ekwiwalent nieuporządkowanej, „nonkonformistycznej” kompozycji filmu. Zob. Interviste a Gato Barbieri e Stefano Zenni, [w:] P.P. Pasolini, Appunti per un’Orestiade.... 
artefakty kulturowe - książka Ajschylosa ${ }^{40}$ oraz mapa Afryki. Grecka tragedia i obcy kontynent pokazany w formie kartograficznej reprezentacji to dla Pasoliniego dwa teksty, których nie można bezpośrednio przedstawić, ale trzeba je odczytać, zinterpretować, pokazać w całym ich dyskursywnym uwikłaniu. Aby to uczynić, reżyser łączy dokument z fikcją, stosuje kreacyjny montaż, w eksperymentalny sposób wiążę obraz z muzyką i nieustannie podważa „przezroczystość” przekazu. Wydaje się, że to sama heterogeniczna i niekonkluzywna forma notatek, a nie werbalizowane przez Pasoliniego, często problematyczne tezy na temat Afryki, czynią z tego eseju audiowizualnego jeden $z$ najbardziej interesujących filmów niefikcjonalnych o tematyce postkolonialnej.

Omawiając notatki Pasoliniego, warto wspomnieć jeszcze o Notatkach do filmu o śmieciarzach (1970), bardzo mało znanym ${ }^{41}$ projekcie, który nigdy nie został sfinalizowany i zachował się jedynie w formie niezmontowanych, pozbawionych ścieżki dźwiękowej materiałów roboczych ${ }^{42}$. Wyprodukowany dla komunistycznego studia Unitelefilm obraz miał przedstawiać rozpoczęty 24 kwietnia 1970 roku strajk pracowników firm wywożących śmieci, którzy zaprotestowali przeciw skandalicznym warunkom pracy. Osiemdziesięciominutowy materiał przedstawia w formie reportażowej wystąpienia przedstawicieli związków zawodowych, wywiady z robotnikami oraz pracę osób zbierających śmieci. Jako że nie są znane prawie żadne wypowiedzi Pasoliniego na temat tego projektu, można jedynie spekulować

${ }^{40}$ Co istotne, jest to egzemplarz wydania, w którym tłumaczem był sam Pasolini, bardzo śmiało poczynający sobie z oryginałem i uwspółcześniający tekst. Na temat przekładu Ajschylosa, dokonanego przez Pasoliniego na początku lat sześćdziesiątych, zob. E. Bal, Cielesność w dramacie. Teatr Pier Paola Pasoliniego i jego możliwe kontynuacje, Kraków 2007, s. 62, 64.

${ }^{41}$ Notatki do filmu o śmieciarzach były dotychczas przedmiotem tylko jednego, włoskojęzycznego tekstu filmoznawczego - zob. R. Chiesi, Gl ultimi uomini „Appunti per un romanzo sull'immondezza” (1970), il film incompiuto di Pasolini, „Cineforum 549” 2015, nr 9, s. 49-52. Projektowi poświęcony został także film dokumentalny Come si fa a non amare Pier Paolo Pasolini - Appunti per un film sull'immondezza (2005) Mimma Caloprestiego.

${ }^{42}$ Materiały z filmu zostały odnalezione w 2005 roku. Więcej na ten temat zob. R. Chiesi, op. cit. 
na temat planowanego kształtu utworu. Materiały robocze nie pozwalają w pełni wykluczyć, że obraz ten miał być filmem o przygotowaniach do dzieła fikcjonalnego ${ }^{43}$, jednak bardziej prawdopodobne wydaje się, iż pojęcie „notatki” w tytule dokumentu miało odsyłać nie tyle do podgatunku „filmów o filmie”, ile do formy brulionu charakterystycznej dla wszelkich esejów audiowizualnych.

\section{CECHY CHARAKTERYSTYCZNE NOTATEK PASOLINIEGO}

Podstawowe cechy, które łączą poetykę notatek filmowych Pasoliniego (a po części też pokrewnych utworów Felliniego i Tarkowskiego) z literacką formą brulionu to: a) heterogeniczność; b) wariantywność c) niekonkluzywność; d) dialogiczność; e) upodmiotowienie przekazu. Warto zastanowić się nad tym, jak cechy te realizują się w medium filmowym i wskazać właściwości charakterystyczne wyłącznie dla przekazów audiowizualnych.

Het er o gen ic z n ość notatek literackich i notatek filmowych jest efektem łączenia różnych stylistyk oraz konfrontowania fikcji z dokumentem, które stanowią o specyfice tej formy wyrazu. Jeżeli chodzi o literaturę, konfrontacja ta może przykładowo dokonywać się w utworach niefikcjonalnych, w których refleksjom artystyczno-warsztatowym towarzyszą fragmenty pisanych przez autorów dzieł, bądź też w powieściach autotematycznych, zestawiających partie fikcjonalne $\mathrm{z}$ fragmentami stylizowanymi na dziennik poświęcony procesowi pisania. Badacze uznają, że tego rodzaju zabiegi były odpowiedzią na kryzys fikcjonalnej literatury, dekonstruowały fabułę i pozwalały na dialog różnych konwencji ${ }^{44}$. W pewnym stopniu analogiczną praktykę można odnaleźć również w notatkach filmowych zderzających pomysły fabularne nie tyle z samą rzeczywistością, ile z konwencjami kina dokumentalnego, pozwalającymi spojrzeć na projektowane dzieła z innych perspektyw. Efektem jest często podważenie schematów fabularnych - przykładowo w notatkach o Indiach i Afryce pomysły Pasoliniego na filmy fikcjonalne ujawniają swoje słabości w zetknięciu z realiami życia ukazanymi w dokumentalno-eseistycznej formie. Różnorodne mate-

43 Pasolini mógł np. zadawać pracownikom pytania związane z przyszłym projektem fabularnym, jednak nie sposób to zweryfikować, dopóki nie zostanie odnaleziona ścieżka dźwiękowa do filmu.

44 Zob. B. Bakuła, op. cit., ss. 59-62, 98. 
riały dokumentalne, takie jak wywiady środowiskowe i ujęcia typu found footage, sprawiają przy tym, że tematy planowanych filmów zostają wzbogacone o szeroki kontekst społeczno-polityczny, który z uwagi na wielość wątków dygresyjnych nie mógłby zostać w takim zakresie uwzględniony w dziełach fabularnych. Trzeba jednak zaznaczyć, że Pasolini nie postuluje w notatkach całkowitego odrzucenia fikcjonalności - zdaniem reżysera sens rzeczywistości można nadać jedynie, projektując na nią opowieść, fikcję, mit. Historie o Chrystusie, maharadży i Orestesie nawet jeśli okazują się nie do końca adekwatnym narzędziem opisu, to jednak pozwalają zobaczyć przedstawiane miejsca oraz ludzi w nowym świetle. Dopiero wzajemne przeglądanie się fikcji i dokumentu prowadzi w notatkach do interesujących wniosków poznawczych.

Autorefleksyjność notatek realizowana jest także na poziomie czysto formalnym, ponieważ jako „bruliony pomysłów twórczych” filmy te zderzają rozmaite techniki i konwencje, które tracą tu swoją „przezroczystość”. O ile Wizja lokalna w Palestynie jest jeszcze względnie jednorodna stylistycznie, o tyle Notatki do Orestei afrykańskiej są złożone z bardzo heterogenicznych materiałów audiowizualnych. Hipotetyczna Oresteja afrykańska zostaje przedstawiona jako opowieść quasi-dokumentalna (materiały found footage), jako kino społeczno-polityczne (ujęcia afrykańskich wiosek, którym towarzyszy pieśń socjalistyczna), jako film na wpół awangardowy (drzewa "grające” rolę Furii przy akompaniamencie muzyki Barbieriego) czy nawet jako kino muzyczne (występ jazzowy). Dzięki formule notatek Pasolini nie musi decydować się na jedno rozwiązanie, ale może pokazywać wielość możliwości rozwoju dzieł fabularnych. Zestawiając różne style, Pasolini z jednej strony wskazuje na różnorodność dyskursów związanych $\mathrm{z}$ podejmowanym tematem, a $\mathrm{z}$ drugiej autorefleksyjnie zwraca uwagę na kreacyjną rolę konwencji i technik filmowych - także we fragmentach niefikcjonalnych. Tym samym w notatkach refleksji poddany zostaje nie tylko model kina fikcjonalnego, ale też dokumentalnego.

Wa ria nt y w n o ść w notatkach literackich występuje wtedy, kiedy autor przedstawia dany fragment tworzonego dzieła w różnych formach stylistycznych lub w różnych wariantach fabularnych, zastanawiając się nad wyborem najlepszej wersji. Przykładem może być dziennik $Z$ dnia na dzień Jerzego Andrzejewskiego, w którym pisarz ukazuje dwie różne „możliwości 


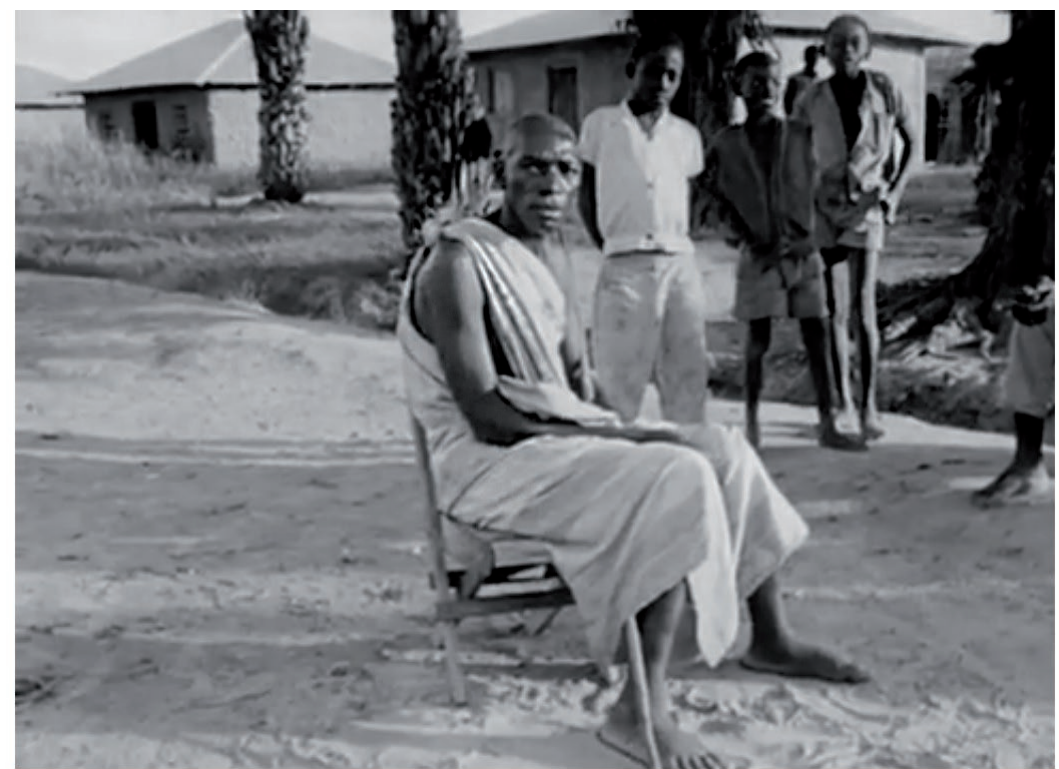

Il. 2. Jeden z potencjalnych Agamemnonów. Kadr z filmu Notatki do Orestei afrykańskiej

rozwinięcia dalszego ciągu"45 ${ }^{31}$ pisanej przez siebie powieści i uzasadnia swoją ostateczną decyzję ${ }^{46}$. Forma powieści skłania pisarza do wyboru jednego, niekoniecznie najlepszego rozwiązania fabularnego, ale notatki pozwalają na zawarcie wielu różnych wersji tekstu, a jednocześnie na przedstawienie wahań autora ${ }^{47}$. W notatkach filmowych Pasoliniego wariantywność nie

45 J. Andrzejewski, $Z$ dnia na dzień..., s. 295.

46 „Z tych dwóch możliwych (rzeczywiście trzeciej nie ma?) do wykorzystania w poniedziałek zanotowanych wersji zdecydowałem się ostatecznie na drugą, lecz o tym wyborze wcale nie racje zadecydowały, po prostu po przemyśleniu obu rozwiązań doszedłem do przekonania, iż przedłużając aż do rana sen Sokrata, tylko na moment rozbudzonego w czas burzy i ulewy, uniknę OPISU jego przeżyć, zyskam natomiast (chyba zbyt często tego słowa używam?) solidniejsze uprawdopodobnienie zapalenia płuc". Ibidem, s. 298.

47 Można mówić o stosowanej przez autorów swoistej retoryce niepewności, polegającej na eksponowaniu własnej niewiedzy co do tego, jak najlepiej napisać powieść. 
dotyczy poziomu fabularnego, ale stylistyki (patrz wyżej) oraz wyboru określonych elementów rzeczywistości prefilmowej - „aktorów” i lokacji. W Notatkach do filmu o Indiach i Notatkach do Orestei afrykańskiej reżyser zestawia ze sobą za pomocą montażu obrazy różnych ludzi, którzy mogliby wcielić się w dane postaci w planowanych przez niego filmach, przy czym pokazywani na ekranie osobnicy niekiedy znacznie różnią się od siebie zgodnie z propozycją twórcy, Agamemnon mógłby być np. ubranym w białą szatę, dostojnym Afrykańczykiem (zob. il. 2), zmęczonym starcem siedzącym na polu, a także Masajem noszącym swój tradycyjny strój. Można sobie wyobrazić, że adaptacja Orestei z każdym z tych „aktorów” byłaby zupełnie inna, a tego rodzaju wariantywność otwiera nowe tropy interpretacyjne dotyczące hipotetycznego filmu ${ }^{48}$. Co istotne, Pasolini nie decyduje nigdy, który „aktor” bądź która lokacja jest najlepsza, ale zawsze wypowiada się w trybie pytającym albo przypuszczającym.

Brak ostatecznych rozstrzygnięć jest przejawem kolejnej cechy notatek - ni ek on klu zy w n ości. Jak wskazują literaturoznawcy, brulionowa forma, pozbawiona jednorodnej struktury i wyraźnego zamknięcia, miała w literaturze oddawać nie tylko niewiedzę autora, ale też bezkształtność, prowizoryczność i tymczasowość rzeczywistości, która nie daje się zamknąć $\mathrm{w}$ konwencjach epickich ${ }^{49}$. W brulionie literackim forma notatek autotematycznych - które mogą w każdej chwili zostać „porzucone” na rzecz innej formy wyrazu, np. dziennika intymnego - kształtowana jest w inny sposób niż w filmie. Notatki audiowizualne Pasoliniego, w całości poświęcone pracy nad filmami, są oddzielnymi utworami, w związku z czym posiadają strukturalnie wyodrębnione zakończenia, które siłą rzeczy mogą być odczytywane przez odbiorcę jako swego rodzaju podsumowanie. W przypadku dwóch ostatnich filmów nie można jednak mówić o mocnych, definitywnych wnioskach - koncepcje dzieł fabularnych Pasoliniego zostają w toku esejów silnie podważone, a pierwotne idee reżysera mogą zaistnieć wyłącznie w formie fragmentu, wieloznacznych metafor, pytań i sugestii.

Odrzucenie apodyktycznego, autorskiego dyskursu, bezpośrednie ustosunkowywanie się pisarzy do innych punktów widzenia na zagadnienia

48 W Notatkach do filmu o Indiach na podobnej zasadzie są tė̇ zestawiane ujęcia pałaców, w których mógłby mieszkać filmowy maharadża.

49 T. Burek, op. cit., s. 35. 
poruszane w tworzonej powieści bądź opowiadaniu oraz dyskusje z odbiorcami to cechy czyniące z notatek literackich formę silnie dia log ic z n ą ${ }^{50}$. $\mathrm{W}$ notatkach filmowych najbardziej oczywistym środkiem kreowania efektu dialogiczności jest pozakad rowy komentarz reżysera, który niekiedy zwraca się do widza w drugiej osobie i kieruje pytania w stronę odbiorcy. Aby uczynić swoje filmy dialogicznymi, Pasolini wykorzystuje jednak także całe spectrum form kina dokumentalnego - do utworów włączane są sondy uliczne oraz rozmowy z ludźmi reprezentującymi różne punkty widzenia. $\mathrm{W}$ notatkach włoskiego reżysera wyjściowa idea zawsze staje się przedmiotem dyskusji. W Wizji lokalnej w Palestynie stałym rozmówcą filmowca jest ksiądz Andrea Carraro, który patrzy na Izrael z religijnej (a nie tak jak Pasolini z estetycznej) perspektywy, z kolei w Notatkach do filmu o Indiach koncepcja przyszłego dzieła fabularnego omawiana jest m.in. $z$ indyjskimi pisarzami i scenarzystami. Najbardziej interesujące pod tym względem są jednak Notatki do Orestei, w których dwukrotnie „akcja” jest przerywana, a fragmenty nagrane przez Pasoliniego w Afryce stają się przedmiotem dyskusji afrykańskich studentów Uniwersytetu w Rzymie. Znamienne jest wprowadzenie tych scen - rozmowa rozpoczyna się od obrazu białego ekranu, na którym studenci oglądali materiały z Afryki (zob. il. 3). Fragmenty afrykańskie, stanowiące główną część Notatek, nabierają przez to charakteru „filmu w filmie", a dyskusje pełnią wobec nich rolę metakomentarza. Co istotne, kamera skupia się przede wszystkim na studentach, którzy nie zgadzają się z twórcą i kwestionują jego pomysły ${ }^{51}$. Filmoznawcy oskarżali niekiedy Pasoliniego o powierzchowność spostrzeżen ${ }^{52}$, jednak trzeba pamiętać, że kontrowersyjne wypowiedzi reżysera są jedynie elementem

50 Dialogiczność w literaturze była szczególnie wyraźna, kiedy pisarz publikował fragmenty dziennika literackiego w prasie (tak jak np. Jerzy Andrzejewski) i mógł bezpośrednio reagować na opinie dotyczące tworzonych przez niego, nieskończonych jeszcze dzieł literackich. Andrzejewski w $Z$ dnia na dzień podejmuje przykładowo polemikę z czytelnikami, którym nie spodobał się rozwój wątku fabularnego w pisanej przez niego powieści. Zob. J. Andrzejewski, op. cit., s. 37-38.

${ }_{51}$ Zwraca na to uwagę komparatysta Massimo Fussillo w Intervista a Massimo Fusillo (docente di Letterature Comparate). Zob. P.P. Pasolini, Appunti per un'Orestiade Africana [DVD], Cineteca di Bologna 2009.

${ }_{52}$ Zob. P. Lopate, In Search of the Centaur, [w:] Essays on the Essays..., s. 123. 
polifonicznej struktury, w ramach której zostają w części zakwestionowane. Co znamienne, ostatecznie artysta nie zdecydował się na nakręcenie utworu fabularnego o Indiach ani nie zrealizował adaptacji Orestei - pozostawił projekty w takiej właśnie, niekonkluzywnej i otwartej formie.

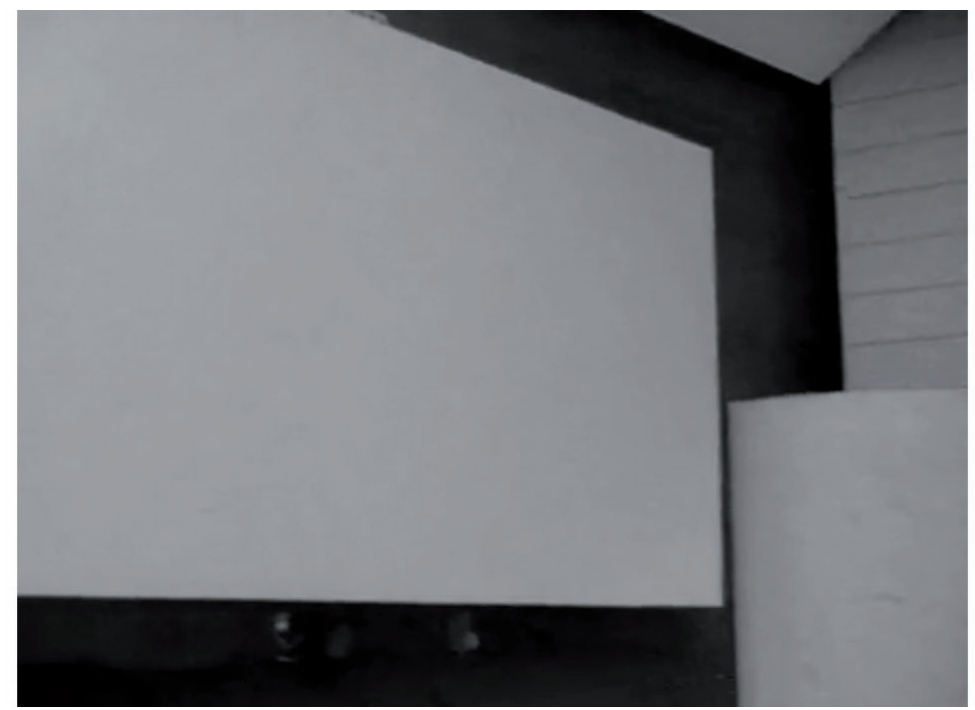

Il. 3. Film $w$ filmie. Kadr $z$ Notatek do Orestei afrykańskiej

Kolejną cechą łączącą notatki filmowe $\mathrm{z}$ analogicznymi formami literackimi jest upodmiotowienie przekazu, które w obydwu mediach staje się jednak przedmiotem krytycznej autorefleksji. Notatki literackie z jednej strony stawiały w centrum figurę autora, ale $\mathrm{z}$ drugiej dekonstruowały obraz stałego, silnego podmiotu literackiego i opowiadały często o uwięzieniu twórcy w języku i konwencjach literackich ${ }^{53}$. Pisarze dawali często wyraz niemożności zapanowania nad językiem i akcentowali, że figura autora w tekście jest konstrukcją językowo-retoryczną, a nie bezpośrednią

53 Zob. cytat: „Wypowiadam się. Więc jestem? Być może. Lecz też i nic nie wiem, co poza moim językowym ograniczeniem chciałaby wypowiedzieć cała reszta mej osobowości, właśnie ta, której wyrazić i nazwać nie potrafię”. J. Andrzejewski, op. cit., s. 404 . 
reprezentacją. Jeśli chodzi o film, podejście do autorstwa jest inne, przede wszystkim z powodu medialnej i semiotycznej odmienności przekazów audiowizualnych. Jednak omawiając notatki, trzeba pamiętać też o kontekście produkcyjnym, instytucjonalnym i historyczno-filmowym. Notatki filmowe powstały w nieprzypadkowym okresie - od początku lat sześćdziesiątych wybrani reżyserzy byli coraz częściej postrzegani jako autorzy filmowi i coraz bardziej rozpoznawalni wśród szerszej publiczności. Nobilitacja artystyczna filmowców oraz zainteresowanie odbiorców (a co za tym idzie także producentów) ich sposobem pracy to czynniki, które nie pozostawały bez wpływu na genezę tej formy filmowej. Aspirujący do miana autorów filmowych reżyserzy mieli ponadto w przypadku notatek wyjątkowo dogodną sytuację, ponieważ ze względu na niewielką skalę tych produkcji dysponowali dużą swobodą twórczą i mogli wykonywać wiele czynności twórczych samodzielnie.

Podczas gdy w Wizji lokalnej Pasolini był jako reżyser jedynie autorem komentarza pozakadrowego i odpowiadał za interakcję słowa i muzyki z obrazem, w Notatkach do filmu o Indiach i Notatkach do Orestei afrykańskiej sprawował pieczę nad wszystkimi elementami organizacji przekazu. Producent drugiego utworu wspomina, że włoski reżyser dobierał materiał wedle własnego uznania i ściśle współpracował z montażystką Cleofe Conversi ${ }^{54}$. Jak mówi Baldi, „to była możliwość, która zasadniczo nigdy nie była osiągalna dla reżyserów w tamtym czasie - miał szansę, żeby przerabiać, zastanawiać się, czekać, przemodelowywać, niszczyć i ponownie tworzyć' ${ }^{55}$. Nie bez znaczenia jest też fakt, że Pasolini używał lekkiej, mobilnej kamery Arriflex $16 \mathrm{~mm}$, którą można było filmować z ręki, co dało twórcy znaczną swobodę w zakresie operowania technologią i umożliwiło spontaniczność rejestracji. Informacje te pokazują, jak istotne przy realizowaniu notatek były możliwości techniczne oraz sprzyjające warunki produkcyjne, jakich twórca z pewnością nie miałby, kręcąc filmy kinowe.

Aby nadać notatkom osobistego charakteru, włoski twórca musiał przezwyciężyć naturalne ograniczenia medium i wykreować ślady autorskie za pomocą technik audiowizualnych. Najbardziej oczywistą autorską sygnaturą jest ekranowa obecność Pasoliniego, który na początku filmów zapowiada

${ }^{54}$ Interviste video a Gian Vittorio Baldi, [w:] P.P. Pasolini, op. cit.

55 Ibidem. 
swoje utwory, patrząc niekiedy prosto w kamerę, co konotuje walor autentyczności. Z wyjątkiem Wizji lokalnej włoski twórca nie pojawia się jednak w notatkach na długo, co wydaje się zrozumiałe, jeśli przyjąć, że chce on wystąpić przede wszystkim w roli podmiotu, a nie przedmiotu obserwacji. Najważniejszym elementem subiektywizującym w notatkach jest montaż oraz pierwszoosobowy komentarz, który nadaje filmom osobistego charakteru i sprawia, że widz patrzy na obraz przez pryzmat słów reżysera. Słowa Pasoliniego dobiegają z innej, pozakadrowej przestrzeni, co sytuuje twórcę ponad światem przedstawionym. Odwołując się do koncepcji znaku Charlesa Peirce’a, można powiedzieć, że komentarz reżysera, umieszczający dokumentalne ujęcia w kontekście projektowanych fabuł, odgrywa w notatkach rolę interpretanta, przy czym sugeruje on odbiorcy znaczenia często bardzo odległe od tego, co faktycznie zostaje pokazane.

Wymownym przykładem są zamieszczone w Notatkach do Orestei materiały archiwalne pokazujące egzekucję przeprowadzoną podczas wojny biafrańskiej w Nigerii, które zdaniem Pasoliniego mogłyby przedstawiać śmierć Agamemnona - surowe, autentyczne zdjęcia wbrew intencjom twórcy nie wpisują się $\mathrm{w}$ ramy mitycznej opowieści. Jak pisze Tomasz Szerszeń, „słowo rozjeżdża się tu z obrazem, tworząc dystans, efekt obcości” ${ }^{56}$. Paradoksalnie, silnie zindywidualizowane notatki filmowe wskazują więc na ograniczone możliwości autora filmowego, który tworzy przekaz z obrazów, bowiem te wymykają się twórcy spod kontroli, są wieloznaczne i ambiwalentne. Niemożliwe jest również stworzenie filmowego autoportretu artystycznego, czego sam Pasolini wydaje się świadomy. Najlepszą metaforą figury autora w notatkach jest ujęcie z początku Notatek do Orestei, w którym reżyser filmuje swoje odbicie w witrynie afrykańskiego sklepu, mówiąc: „Przyszedłem tu filmować - ale co filmować? Nie dokument ani film. Przyszedłem tu filmować notatki do filmu" (zob. il. 4). Ten symboliczny obraz nie tylko zapowiada, że wizja Afryki będzie subiektywna, lecz także wskazuje na problematyczny status autora filmowego, który może zaistnieć w przekazie audiowizualnym wyłącznie jako ślad, niewyraźne odbicie na przedstawianej rzeczywistości.

56 T. Szerszeń, Szyby Afryki, op. cit., s. 7. 


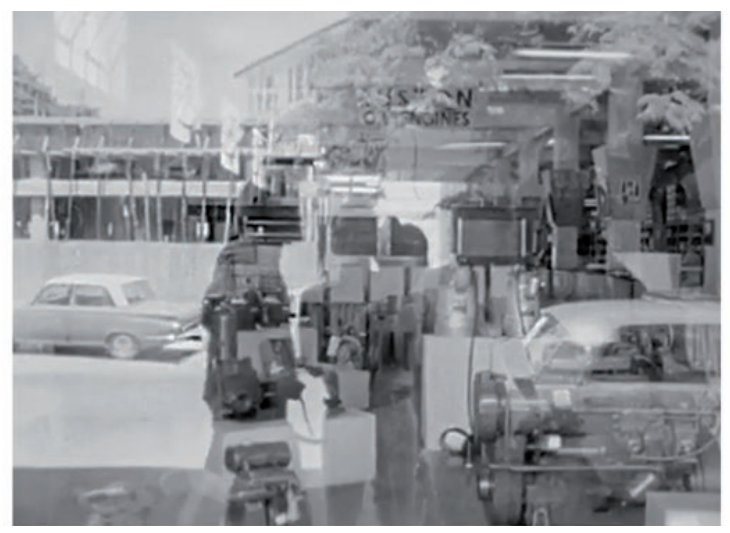

Il. 4. Palimpsestowy obraz. Kadr z Notatek do Orestei afrykańskiej

Powyższe cechy mogą świadczyć o pewnych literacko-filmowych analogiach, jednak niektóre właściwości poetyki notatek filmowych wiążą się wyłącznie ze specyfiką medium audiowizualnego. Najważniejszą z nich jest szczególne przedstawienie przestrzeni, które można nazwać palimpsestowym. Wspomniane ujęcie pokazujące Pasoliniego przeglądającego się w szybie wydaje się w tym kontekście symboliczne. Wnętrze sklepu widoczne zza witryny, tafla szyby oraz odbijające się w niej obiekty zewnętrzne zlewają się ze sobą na ekranie i tworzą jedną heterogeniczną całość. Widz może zidentyfikować tylko poszczególne kształty - sylwetkę Pasoliniego z kamerą, niektóre ze sprzedawanych w sklepie produktów, nowoczesne samochody stojące na ulicy czy rozłożyste afrykańskie drzewo. Kadr ten skupia w sobie wszelkie sprzeczności filmowych notatek: łączy rzeczywistość z jej wizualną reprezentacją, naturę ${ }^{57} \mathrm{z}$ kulturą, obiektywizm dokumentalnych zdjęć z figurą autora. Oczywiście palimpsestowy ${ }^{58}$ obraz może pojawiać się w ramach rozmaitych gatunków i konwencji filmowych, jednak forma notatek szczególnie uprzywilejowuje tego rodzaju konstrukcję - filmowana w trybie dokumentalnym, realna czasoprzestrzeń staje

57 Jak się później okaże, drzewa w adaptacji Orestei mają „występować” w roli Furii, symbolizujących prehistoryczną Afrykę.

58 Na palimpsestowy charakter ujęcia z Pasolinim zwraca uwagę też Tomasz Szerszeń. Zob. T. Szerszeń, op. cit., s. 1. 
się bowiem w notatkach potencjalnym miejscem akcji przyszłych dzieł fikcjonalnych. Wskutek tego obrazy mają podwójną referencję, ponieważ odsyłają zarówno do realnych obiektów, jak i do wyobrażonych obiektów z planowanych filmów. Podstawowym zabiegiem kompozycyjnym staje się interferencja - nakładanie się różnych poziomów czasoprzestrzennych i ontycznych - osiągana głównie dzięki szczególnemu powiązaniu obrazu z komentarzem słownym i muzyką oraz montażowi.

Posługując się tym zabiegiem, twórca notatek podejmuje refleksję natury semiotycznej na temat tych właściwości medium filmowego, które nie mają ekwiwalentów na gruncie literatury. Przekaz audiowizualny (przynajmniej w okresie sprzed rewolucji cyfrowej) konstytuowany jest poprzez mechaniczną reprodukcję rzeczywistości znajdującej się przed kamerą ${ }^{59}$, co stwarza przed filmowcami problemy zupełnie innego rodzaju niż te, z jakimi mierzą się pisarze tworzący za pomocą słowa. Można uznać, że notatki filmowe są świadectwem zmagań reżysera, który próbuje nadbudowywać znaczenia nad obrazami rzeczywistości fizykalnej. Należy też dodać, że refleksja nad reprezentacją wykracza poza autotematyczne rozważania i jest osadzona w szerszym kontekście społeczno-kulturowym - za pomocą samoświadomej, brulionowej formy Pasolini kreuje strategię opowiadania o kulturach zmarginalizowanych w zachodnim dyskursie.

W ramach podsumowania można stwierdzić, że forma notatek nie została sztucznie przeszczepiona z literatury do filmu, ale była wypracowywana stopniowo, a na powstanie i rozwój tej odmiany eseju audiowizualnego miały wpływ takie czynniki, jak: popularność teorii kina autorskiego, technologia, dostępne kanały dystrybucji (telewizja ${ }^{60}$ ), a także indywidualny wkład filmowców - przede wszystkim Piera Paola Pasoliniego. Ponieważ włoski twórca był także autorem powieści, opowiadań i esejów, można założyć, że

59 Zob. M. Hopfinger, Adaptacja jako przejaw relacji między literatura a filmem. Intersemiotyczne podstawy adaptacji, [w:] idem, Adaptacje filmowe utworów literackich. Problemy teorii i interpretacji, Wrocław 1974, s. 77.

${ }^{60}$ Notatki do filmu o Indiach i Notatki do Orestei afrykańskiej Pasoliniego oraz Czas podróży Tarkowskiego zostały zrealizowane dla telewizji RAI, a Notatnik reżysera Felliniego dla telewizji NBC. Notatki na temat filmu „Zdrowaś Mario” Godarda były natomiast produkcją wideo zrealizowaną przez twórcę, by pozyskać fundusze na dzieło fabularne. 
literatura znacząco wpłynęła na jego myślenie o filmie i autorstwie filmowym. Bezpośrednią inspiracją była jednak forma audiowizualna - reżyser dostrzegł potencjał tkwiący w Wizji lokalnej w Palestynie, która w zamyśle miała być utworem czysto użytkowym, i świadomie rozwijał formułę stworzoną w tym filmie. Notatki do filmu o Indiach nie były już jedynie relacją reżysera z etapu preprodukcji, ale dziełem podejmującym refleksję nad tym, czy fikcjonalny, fabularny utwór w ogóle może powstać. W przypadku Notatek do filmu o Orestei metatekstualność stała się samoistną, autonomiczną strategią opowiadania o rzeczywistości - reżyser prawdopodobnie nie miał zamiaru kręcić filmu fabularnego i uznał, że Oresteję afrykańskg najlepiej zrealizować właśnie w formie notatek. Warto dodać, że pod koniec życia reżyser Pasolini często stosował poetykę fragmentu nie tylko w filmie, ale też w tekstach literackich (np. w niedokończonej powieści Petrolio).

Ogólne cechy analizowanych utworów Pasoliniego są charakterystyczne dla całego gatunku eseju filmowego, jednak warto uznać notatki za odrębną odmianę tej formy filmowej, ponieważ tworzą one unikatową grupę utworów poświęconych samemu procesowi pracy nad filmem ${ }^{61}$. Ich cechą dystynktywną jest metatekstualność sprawiająca, że filmy te zawsze są odczytywane w relacji do innych, jeszcze nieistniejących, wirtualnych, czysto potencjalnych dzieł. Z uwagi na metatekstualny charakter, obrazy w notatkach mają podwójną referencję, a ich znaczenia jawnie wykraczają poza poziom denotacji, co uruchamia refleksyjny, krytyczny typ „lektury”. Niefikcjonalny tryb opowiadania umożliwia inkluzję luźnych, nieukładających się w fabułę

${ }_{61}$ Tematyczne i stylistyczne podobieństwa w Wizji lokalnej w Palestynie, Notatkach do filmu o Indiach i Notatkach do Orestei afrykańskiej, a także w Notatniku reżysera Felliniego i Czasie podróży Tarkowskiego przemawiają za tym, by ujmować te dzieła wspólnie i traktować jako odmianę eseju filmowego. Badacze nazywają niekiedy wszystkie filmy niefikcjonalne Pasoliniego mianem "notatek”, a Maurizio Tisei uznaje za filmy „notatkowe” też takie utwory, jak: Fata Morgana (1969) Wenera Herzoga i Dziennik intymny (1993) Nanniego Moettiego. Zob. M. Tisei, Il „cinema per appunti” di Pier Paolo Pasolini [nieopublikowana praca dyplomowa], Uniwersytet Rzymski „La Sapienza”, Rzym 1994-1995, s. 206-216. Wydaje się jednak, że taka nomenklatura jest mało funkcjonalna, ponieważ pojęcie to staje się wówczas synonimem eseistyki filmowej. Dlatego uważam, że warto ograniczyć nazwę „notatek” do filmów poświęconych przygotowaniom do realizacji innych filmów. 
fragmentów dokumentalnych, a formuła „filmu o filmie”, otwarcie podkreślająca pośrednictwo medium filmowego, pozwala na odejście od naiwnego, pozorującego obiektywizm realizmu. Notatki są dzięki temu nie tylko filmami o tworzeniu filmów, wskazującymi na wielość możliwych stylistycznych wariantów i ścieżek rozwoju potencjalnych dzieł fikcjonalnych, ale też utworami postulującymi refleksyjny sposób przedstawiania rzeczywistości.

Forma notatek filmowych oraz refleksje w nich podejmowane pozwalają mówić o wyraźnych analogiach z autotematycznymi notatkami literackimi. Podobnie jak literaci, filmowcy opowiadają o redukcjonizmie zamkniętych struktur fabularnych oraz o ograniczeniach twórczości opartej wyłącznie na fikcji, a także problematyzują zagadnienie autorstwa. Odmienność medialna notatek literackich i notatek filmowych jest jednak przyczyną zasadniczych różnic. Podczas gdy autorzy notatek literackich stylizowali je często na spontaniczne zapiski i posługiwali się konwencjami charakterystycznymi dla intymistyki, Pasolini robi użytek z konwencji kina dokumentalnego, co sprawia, że notatki filmowe są znacznie mniej subiektywne niż notatki literackie. Dokumentalne formy wyrazu wzbogacają jednak audiowizualny dyskurs autotematyczny na inne sposoby - przykładowo formuła reportażu, w ramach której inne podmioty zyskują „prawo głosu”, w istotny sposób kształtuje polifoniczną strukturę tych utworów. Kolejne różnice wynikają z odmiennego statusu twórcy w literaturze i filmie - niezależnie od stopnia swobody artystycznej, reżyser notatek filmowych pozostaje jedynie organizatorem i interpretatorem audiowizualnego materiału. Zarówno realizatorzy notatek filmowych, jak i twórcy analogicznych form literackich przedstawiają swoje zmagania $\mathrm{z}$ materią przekazu, jednak w obydwu wypadkach mają one odmienny charakter. Podczas gdy pisarze opowiadają o niemożności wyrażenie siebie poprzez język, konwencje i gatunki literackie, Pasolini m.in. pokazuje, jak trudno jest sfunkcjonalizować obrazy realnej rzeczywistości na rzecz filmu.

Można zastanawiać się, dlaczego notatki filmowe przestały powstawać w połowie lat osiemdziesiątych, pomimo że technologia wideo, a następnie media cyfrowe, znacznie ułatwiłyby realizację oraz dystrybucję utworów tego typu. Wydaje się, że przyczyną był zmierzch modernistycznego modelu kina autorskiego oraz odmienny kierunek rozwoju postmodernistycznej eseistyki. Choć notatki przynależą do innej epoki historyczno-filmowej, w dalszym ciągu wydają się interesującym materiałem badawczym. Po pierwsze, 
dlatego że dają wgląd nie tyle w pracę organizacyjną, co w proces artystyczny. Notatki Pasoliniego, Felliniego, Tarkowskiego charakteryzują się - choć w różnym natężeniu - podobnym zestawem cech: otwartością formalną, heterogenicznością, dialogicznością i subiektywizmem² ${ }^{62}$. Jednocześnie jednak w utworach każdego z tych twórców ujawnia się inny rodzaj relacji między rzeczywistością fizykalną a obrazem filmowym. Przykładowo Pasolini akcentuje napięcia między obydwiema sferami, natomiast Fellini znosi różnicę i w konwencji bliskiej mockumentowi przedstawia rzeczywistość jako spektakl. Porównanie „notatkowych” utworów mogłoby przynieść rozpoznania na temat odmiennego semiotycznego podejścia tych reżyserów do sztuki filmowej. Po drugie, rozważania Pasoliniego nad kategorią miejsca oraz nad rolą ciała ludzkiego w filmie wydają się inspirujące nawet w epoce kina cyfrowego - włoski reżyser zwraca bowiem uwagę na gęstą sieć znaczeń, w jakie uwikłane są elementy prefilmowe ${ }^{63}$. Po trzecie wreszcie, dzieła włoskiego reżysera są interesujące z perspektywy komparatystycznej. Choć bowiem w notatkach literackich i w notatkach filmowych można odnaleźć analogiczne zagadnienia, tendencje i zabiegi, to jednak konteksty medialne $\mathrm{w}$ istotny sposób zmieniają ich formę oraz konfigurację. Podczas gdy z perspektywy semiotycznej w notatkach literackich najistotniejsze wydaje się napięcie między znaczącym a znaczonym, reprezentantem a interpretantem, w notatkach filmowych kluczowa jest relacja pomiędzy reprezentantem i interpretantem a sferą przedmiotową, która wnosi do przekazów audiowizualnych własne znaczenia, ma palimpsestowy charakter i nie daje się „podporządkować” koncepcji twórcy.

62 Eseistyczne Notatki na temat filmu „Zdrowaś Mario” to obraz nieco odmienny, ponieważ Godard nie opowiada o poszukiwaniach lokacji czy aktorów. Pokazując próby z aktorką oraz dyskusje na temat muzyki, która zostanie wykorzystana w Zdrowaś Mario (1985), reżyser również tematyzuje proces nadawania znaczeń w filmie.

63 Pasolini, który stworzył własną koncepcję semiotyczną, uważał, że ludzkie działania same w sobie tworzą "język”, a kino jest środkiem zapisu owego „języka rzeczywistości”. P.P. Pasolini, Język pisany rzeczywistości, tłum. M. Salwa [w:] idem, Po ludobójstwie. Eseje o języku, polityce i kinie, red. M. Werner, Kronos, Warszawa 2012, s. 97-135. Daleka od akademickich rygorów teoria reżysera była przez długi czas oskarżana o nienaukowość, jednak po latach doczekała się reinterpretacji ze strony filmoznawców, którzy dostrzegli w niej wiele prekursorskich i inspirujących myśli. 


\section{Bibliografia}

Jerzy Andrzejewski, Miazga, Ossolineum, Wrocław 2002.

Jerzy Andrzejewski, Z dnia na dzień 1976-1979, tom 2, Czytelnik, Warszawa 1988.

Bogusław Bakuła, Oblicza autotematyzmu, WiS, Poznań 1991.

Ewa Bal, Cielesność w dramacie. Teatr Pier Paola Pasoliniego i jego możliwe kontynuacje, Księgarnia Akademicka, Kraków 2007.

Anna Bersotti, Il mito greco e la tragedia in Pier Paolo Pasolini: Appunti per un'Orestiade Africana [niepublikowana praca dyplomowa], Università Ca' Foscari, Wenecja 2014.

Marco Bertozzi, Storia del documentario italiano: immagini e culture dell'altro cinema, Marsilio, Wenecja 2008.

Wojciech Browarny, Opowieści niedyskretne: formy autorefleksyjne w prozie polskiej lat dziewięćdziesiątych, Wydawnictwo UWr, Wrocław 2002.

Tomasz Burek, Zamiast powieści, Czytelnik, Warszawa 1971.

Luca Caminati, Orientalismo eretico. Pier Paolo Pasolini e il Cinema del Terzo Mondo, Bruno Mondadori, Mediolan 2007.

Roberto Chiesi, Gl ultimi uomini „Appunti per un romanzo sull'immondezza” (1970), il film incompiuto di Pasolini, „Cineforum 549” 2015, nr 9.

Roberto Chiesi, Pasolini e la 'Nuova Forma' di appunti per un'Orestiade Africana, [w:] Appunti Per Un'Orestiade Africana, a cura di R. Chiesi, Cineteca di Bologna, Bolonia 2008, [książka dołączona do DVD].

Timothy Corrigan, The Essay Film. From Montaigne, After Marker, Oxford University Press, New York 2001.

Roman Costa, L'India di Pasolini, „Vie Nuove”, 25.01.1968, [przedruk w:] P.P. Pasolini, Le Regole Di Un'Illusione. I film, il cinema, a cura di L. Betti, M. Gulinucci, Associazione „Fondo Pier Paolo Pasolini”, Roma 1991.

Marianna De Palma, Pasolini. Il Documentario di poesia, Falsopiano, Aleksandria 2009.

Gilles Deleuze, Kino. Obraz-ruch. Obraz-czas, tłum. J. Margański, słowo/obraz terytoria, Gdańsk 2008.

Essays on the Essay Film, eds. N.M. Alter, T. Corrigan, Columbia University Press, New York 2017.

Maryla Hopfinger, Adaptacja jako przejaw relacji między literatura a filmem. Intersemiotyczne podstawy adaptacji, [w:] idem, Adaptacje filmowe utworów literackich. Problemy teorii i interpretacji, Ossolineum, Wrocław 1974.

Piotr Kletowski, Między dokumentalnym ujęciem a kreacją. Dokufilmy Pier Paolo Pasoliniego, „Kultura Popularna” 2013, nr 1(35).

Piotr Kletowski, Pier Paolo Pasolini. Twórczość filmowa, Sedno, Warszawa 2013.

Piotr Kletowski, W kręgu mitów założycielskich - (przed)historyczne kino Piera Paola Pasoliniego, [w:] Przeszłość we współczesnej narracji kulturowej. Tom 2. Studia i szkice kulturoznawcze, red. P. Plichta, Wydawnictwo UJ, Kraków 2011. 
Tomasz Kożuchowski, Making-of. (Nie)zwykły dodatek, „Ekrany” 2019, nr 3-4.

Erazm Kuźma, Między konstrukcją a destrukcją: szkice z teorii i historii literatury,

Wydawnictwo Naukowe US, Szczecin 1994.

Wilhelm Mach, Góry nad Czarnym Morzem, Czytelnik, Warszawa 1961.

Armando Maggi, The Resurrection of the Body: Pier Paolo Pasolini from Saint Paul to

Sade, University of Chicago Press, Chicago 2009.

Tomasz Mann, Jak powstał doktor Faustus. Powieść o powieści, tłum. M. Kurecka,

Czytelnik, Warszawa 1962.

Marshall McLuhan, Zrozumieć media. Przedłużenia człowieka, tłum. N. Szczucka, WNT, Warszawa 2004.

David Montero, Thinking Images. The Essay Filmas a Dialogic Form in European Cinema, Peter Lang AG, Internationaler Verlag der Wissenschaften, Berno 2012.

Ryszard Nycz, Sylwy współczesne, Universitas, Kraków 1996.

Pier Paolo Pasolini, Appunti per Un'Orestiade Africana, a cura di A. Costa, Quaderni del Centro Culturale, Copparo 1983.

Pier Paolo Pasolini, Notes for a Poem on the Third World, [w:] idem, My Cinema, eds.

G. Chiarcossi, R. Chiesi, Fondazione Cineteca di Bologna, Bolonia 2012.

Pier Paolo Pasolini, Pier Paolo Pasolini: A Future Life (A Cinema of Poetry), eds. L. Betti, Associazione "Fondo Pier Paolo Pasolini”, Lazio 1989.

Pier Paolo Pasolini, Po ludobójstwie. Eseje o jezzyku, polityce i kinie, red. M. Werner, Kronos, Warszawa 2012.

Pier Paolo Pasolini, The Scent of India, transl. D.C. Price, CreateSpace Independent Publishing Platform, London 2012.

Pier Paolo Pasolini, The White Athena, [w:] idem, My Cinema, eds. G. Chiarcossi, R. Chiesi, Fondazione Cineteca di Bologna, Bolonia 2012.

Laura Rascaroli, How the Essay Film Thinks, Oxford University Press, Oxford-New York 2017.

Laura Rascaroli, The Personal Cinema. Subjective Cinema and the Essay Film, Wallflower Press, New York 2009.

Grażyna Świętochowska, Wideoesej, czyli od Chrisa Markera do Fandoru. Historia awansu pewnej formy audiowizualnej wyrosłej z kinofilii, „Kwartalnik Filmowy” 2018, nr 104.

Maurizio Tisei, Il „cinema per appunti” di Pier Paolo Pasolini [nieopublikowana praca dyplomowa], Uniwersytet Rzymski „La Sapienza”, Rzym 1994-1995.

Maurizio Viano, A Certain Realism. Making Use of Pasolini's Film Theory and Practice, University of California Press, Berkeley 1993.

Bartosz Zając, Między słowem a obrazem. Dyskurs eseju filmowego, „Kwartalnik Filmowy" 2010, nr 71-72. 


\section{Źródła internetowe}

Tomasz Szerszeń, Szyby Afryki, „Widok. Teorie i Praktyki Kultury Wizualnej” 2014, nr 7 [czasopismo internetowe], http://widok.hmfactory.com/index.php/one/ $\operatorname{article/view/221/385~[dostęp~13.03.2020].~}$

\section{Materiały audiowizualne}

Interviste a Gato Barbieri e Stefano Zenni, [w:] P.P. Pasolini, Appunti per un'Orestiade Africana [DVD], Cineteca di Bologna 2009.

Intervista a Massimo Fusillo (docente di Letterature Comparate), [w:] P.P. Pasolini, Appunti per un'Orestiade Africana [DVD], Cineteca di Bologna 2009.

Interviste video a Gian Vittorio Baldi, [w:] P.P. Pasolini, Appunti per un'Orestiade Africana [DVD], Cineteca di Bologna 2009.

\section{Pier Paolo Pasolini's Film 'Notes' in the Context of Literary and Film Poetics of Draft}

The article is devoted to the form of film 'notes', defined by the author as nonfictional films depicting preparations for the production of fictional works. The author describes this particular subgenre of film essay in the context of other forms of self-referential non-fictional cinema, and also comparatively confronts it with self-referential literary notes, in which writers present their creative process. The subject of the analysis are three works realized by Pier Paolo Pasolini: Sopralluoghi in Palestina per il vangelo secondo Matteo (1965), Appunti per un film sull'India (1968), Appunti per un'Orestiade Africana (1970). The author draws attention to the production of these films and describes the process of shaping the 'notes' formula in the films of the Italian director. The article then discusses the main features of the form of 'notes', such as: heterogeneity, variability, polyphony and the subjectivity. As the author argues, although analogous tendencies can be found in literary notes and film 'notes', media contexts significantly change their form and configuration. While in literary notes the tension between the signifier and the signified seems to be the most important, in film 'notes' the most important is the relationship between the interpretant and the objects, which cannot be 'subordinated' to the concept of the film director.

Keywords: film 'notes', literary notes, self-reflexivity, comparative studies, film, literature, Pier Paolo Pasolini, film essay, semiotics, Italian cinema

Data otrzymania tekstu: 15.04.2020 r.

Data zakończenia procesu recenzyjnego: 3.05.2020 r.

Data akceptacji tekstu do druku: 10.05.2021 r. 